\title{
Changes in Methylation and Structure of DNA from Almond Tissues during in vitro Culture and Cryopreservation
}

\author{
Chockpisit Channuntapipat, Margaret Sedgley, and Graham Collins ${ }^{1}$ \\ School of Agriculture and Wine, Waite Campus, University of Adelaide, PMB \#1, Glen Osmond, South \\ Australia 5064, Australia
}

\begin{abstract}
Additional Index words. Prunus, germplasm, genetic stability, fingerprint, methylation
Abstract. Leaf explants were taken from mature leaves of two almond [Prunus dulcis (Miller) D.A. Webb] cultivars, Ne Plus Ultra and Nonpareil selection 15-1, and maintained in vitro to grow shoot tips. Shoot tips were grown also from a pre-existing in vitro culture of an almond-peach rootstock, $P$. dulcis 'Titan' $\times P$. persica 'Nemaguard'. The shoot tips were harvested, cryopreserved, and tested for survival after 3 days and then at intervals of 3 months up to two years. The mean survival was $80 \%$ for 'Ne Plus Ultra', 54\% for 'Nonpareil', and $78 \%$ for the hybrid rootstock, and there were no significant differences in survival between 3 days and 24 months. The effects of in vitro culture and cryopreservation on DNA integrity were examined by both RAPD-PCR, and restriction enzyme digestion followed by RAPD-PCR, using DNA from the original trees from which the explants were derived, from leaves regrown from cultures that had undergone several passages of in vitro culture, and from leaves regrown from cryopreserved shoot tips. No detectable differences were found between the DNA fingerprints of each DNA sample using RAPD-PCR with seven different 10-mer primers. However, differences were detected when the DNA was first digested with the isoschizomeric pairs, Hpa II/Msp I and Bsp $143 \mathrm{I} / \mathrm{Mbo}$ I and then subjected to RAPD-PCR with six different 10-mer primers. Changes in the structure and methylation of DNA were found that were probably related to the process of in vitro culture, and in addition, methylation changes were detected that were probably associated with the cryopreservation process. These changes did not appear to be caused by the vitrification solution used before immersion of shoot tips in liquid nitrogen. While cryopreservation appears to be an ideal method for the long-term storage of almond germplasm, the significance of the alterations to both methylation and structure of DNA needs to monitored in regenerated plants, especially as they relate to agronomic performance when the regenerants become reproductively mature.
\end{abstract}

Conventional methods of maintaining fruit tree crops for germplasm preservation require extensive space and labor, and the plants are subject to attack by pathogens and pests. One possibility for germplasm preservation is in vitro tissue culture. However, spontaneous mutations (Elleuch et al., 1998) and changes in methylation (Harding et al., 1996; Rao and Riley, 1994) have been reported to occur with some plant tissues during this process. Cryopreservation at the temperature of liquid nitrogen $\left(-196^{\circ} \mathrm{C}\right)$ appears to be ideal for long-term suspension of the metabolic activities of living tissue. In recent years, cryopreservation of plant cells, meristems, and organs has been used for the long-term preservation of plant germplasm (Takagi et al., 1997) and has potential for conservation of genetic resources of fruit trees (Niino et al., 1997). Morphogenetic development of tissues does not appear to be affected by cryopreservation, and plants that are regenerated seem to be normal (Rao and Riley, 1994). The technique has been successfully applied to many types of plant cultures such as callus, cell suspension, protoplasts, embryogenic callus, embryos, small plantlets, meristems, and shoot tips of a number of different species (Stushnoff and Fear, 1985). However, for germplasm preservation, meristems or shoot tips are more desirable than other kinds of explants (Uemura and Sakai, 1980), and a technique has been developed to successfully cryopreserve almond [Prunus dulcis (Miller) D.A. Webb] shoot tips (Channuntapipat et al., 2000).

There are no reports of genetic changes to almond tissues during in vitro culture, although the possibility exists that genetic stability could be affected by cryopreservation because of stresses

Received for publication 3 Dec. 2002. Accepted for publication 24 June 2003. 'To whom reprint requests should be addressed; e-mail graham.collins@adelaide. edu.au. resulting from the cryoprotectants, the high osmotic pressure of the dehydrating solution, and the exposure to low temperature (Benson and Hamill, 1991).

Changes in DNA can occur by structural changes and by methylation. Structural change, including insertions and deletions of base pairs, can be detected as length polymorphisms by techniques such as RAPD-PCR. This technique has been used to assess the structural stability of plant material from in vitro propagation (Goto et al.. 1998), and cryopreservation (De Verno et al., 1999; Elleuch et al., 1998). Changes in methylation occur at sufficiently high frequencies to be an important cause of tissue culture-induced variation (Kaeppler and Phillips, 1993). Methyl groups are enzymatically transported to different positions on cytosine by DNA methyltransferase activity (McClelland et al., 1994). The level of DNA methylation in plants is modulated during development and differentiation (Weber et al., 1990), and can be detected by isoschizomers of restriction endonucleases that differ in their sensitivity to methylation (McClelland et al., 1994).

Channuntapipat et al. (2000) reported a method to cryopreserve shoot tips of two almond cultivars and an almond-peach hybrid. This paper reports on the viability of these shoot tips after long-term storage of up to 24 months in liquid nitrogen, and assessment, by a combination of restriction digestion and RAPD-PCR, of changes to both the structure and methylation status of DNA extracted from plant material after both in vitro culture and cryopreservation.

\section{Materials and Methods}

Plant material and in vitro culture conditions. Three leaves were collected from each of two trees of the almond cvs. 'Ne Plus Ultra' and 'Nonpareil' selection 15-1. Explants from the 
Table 1 Isoschizomer pairs of restriction enzymes, differing in their sensitivity to sequence-specific methylation, used to detect changes in methylation of almond DNA.

\begin{tabular}{|c|c|c|c|}
\hline Restriction & Recognition & Met & tion sensitivity \\
\hline enzyme & sequences & Cut & Not cut \\
\hline$\overline{\mathrm{Hpa} \mathrm{II}}{ }^{\mathrm{z}}$ & $\begin{array}{l}5^{\prime} \mathrm{C}^{t} \mathrm{CGG} 3^{\prime} \\
3^{\prime} \mathrm{GGCsC} 5^{\prime}\end{array}$ & CCGG & ${ }^{\mathrm{m} C C G G}$ and $\mathrm{C}^{\mathrm{m} C G G}$ \\
\hline Msp I ${ }^{z}$ & $\begin{array}{l}5^{\prime} \mathrm{C}^{\prime} \mathrm{CGG} 3^{\prime} \\
3^{\prime} \mathrm{GGCsC} 5^{\prime}\end{array}$ & $\mathrm{C}^{\mathrm{m}} \mathrm{CGG}$ & ${ }^{\mathrm{m}} \mathrm{CCGG}$ and ${ }^{\mathrm{m}} \mathrm{C}^{\mathrm{m}} \mathrm{CGG}$ \\
\hline $\begin{array}{l}\text { Bsp } 143 \text { Iy } \\
\text { (Sau 3a I) }\end{array}$ & $\begin{array}{l}5^{\prime} \text { 'GATC } 3^{\prime} \\
3^{\prime} \text { CTAGs 5' }\end{array}$ & GATC & $\mathrm{GAT}^{\mathrm{m}} \mathrm{C}$ \\
\hline $\begin{array}{l}\text { Mbo Iy } \\
\text { (Nde II) }\end{array}$ & $\begin{array}{l}5^{\prime} \text { 'GATC 3' } \\
3^{\prime} \text { CTAGs 5' }\end{array}$ & GATmC & GATC \\
\hline
\end{tabular}

zFrom Weber et al. (1990), Kaeppler et al. (1993); McClelland et al. (1994); Harding et al. (1996); Kovař́ík et al. (1997).

yFrom Weber et al. (1990); McClelland et al. (1994); and Franks et al. (1998).

leaves of 'Ne Plus Ultra' were cultured on Murashige and Skoog (MS) medium (Murashige and Skoog, 1962) supplemented with $0.049 \mu \mathrm{M}$ indole-3 butyric acid (IBA), $4.44 \mu \mathrm{M}$ 6-benzyl-aminopurine (BAP), $0.088 \mathrm{M}$ sucrose, and $0.7 \%(\mathrm{w} / \mathrm{v})$ agar (Difco, Bitek). Explants from the leaves of 'Nonpareil' were cultured on Almehdi and Parfitt (AP) medium (Almehdi and Parfitt, 1986) supplemented with $0.049 \mu \mathrm{M}$ IBA, $3.1 \mu \mathrm{M}$ BAP, $0.058 \mathrm{M}$ sucrose, and $0.7 \%$ agar. The $\mathrm{pH}$ of both media was adjusted to 5.7 before adding agar and autoclaving at $121{ }^{\circ} \mathrm{C}$ for $20 \mathrm{~min}$. In addition, in vitro cultured shoots of an almond-peach hybrid rootstock $(P$. dulcis 'Titan' $\times P$. persica 'Nemaguard'), provided by ForBio Research Pty. Ltd., were cultured on the same medium as ' $\mathrm{Ne}$ Plus Ultra'. The original source of the rootstock cultures is not known. All cultures were maintained in $250 \mathrm{~mL}$ polypropylene pots containing $50 \mathrm{~mL}$ of culture medium, incubated under cool white fluorescent light $\left(40 \mu \mathrm{mol} \cdot \mathrm{m}^{-2} \cdot \mathrm{s}^{-1}\right)$ with $16 \mathrm{~h}$ photoperiod at $25 \pm 1^{\circ} \mathrm{C}$, and subcultured every 4 to 5 weeks.

Storage by CRYOPRESERVATION. Shoot tips were cryopreserved as described by Channuntapipat et al. (2000). Explants with shoots were cold-hardened at $4{ }^{\circ} \mathrm{C}$ for $21 \mathrm{~d}$, and then shoot tips with 3 to 5 leaf primordia ( 2.0 to $2.5 \mathrm{~mm}$ long, 1.0 to 1.5 $\mathrm{mm}$ base diameter) were dissected. The shoot tips were incubated in the PVS2 vitirification solution of Sakai et al. (1991) and stored in liquid nitrogen. Each treatment was replicated 12 times with 10 shoot tips per replication, and shoot tips with different origins were kept in separate cryotubes for identification during all stages. All shoot tips within a replication were of the same age. After $3 \mathrm{~d}$ and then at intervals of 3 months up to 24 months, shoot tips were thawed at $30{ }^{\circ} \mathrm{C}$ and cultured on the same media that were used before cryopreservation. Survival was recorded as the percentage of cryopreserved shoot tips that produced new shoots 4 weeks after thawing.

Statistical ANALYSis. The cultures were arranged as completely randomized designs and the data were analyzed using Duncan's new multiple range test. Calculation of standard errors of the means were carried out using PlotIT v 3.20i (Scientific Programming Enterprises, Haslett, Mich.).

LEAF SAMPLES USED FOR DNA ANALYSIS. Tissues that were analyzed included leaves as follows:

a) from orchard trees from which the original explants were obtained,

b) regenerated from in vitro cultures that had not been cryopreserved,

c) regenerated from shoot tips that had been cryopreserved for
$3 \mathrm{~d}$,

d) regenerated from shoot tips that had been cryopreserved for 24 months,

e) from a plant grown from an in vitro culture that had not been cryopreserved,

f) from a plant grown from an in vitro culture that had been cryopreserved for $3 \mathrm{~d}$, and

g) generated from in vitro cultures that had been treated with vitrification solution only.

Preparation of genomic DNA. Leaf samples were bulked to obtain $\approx 1.5 \mathrm{~g}$, and genomic DNA was extracted using the technique of Mekuria et al. (1999). The quantity and quality of the DNA preparations were assessed by measuring the absorbances at 230,260 , and $280 \mathrm{~nm}$ and calculating the ratios of $\mathrm{A}_{260} / \mathrm{A}_{230}$ and $\mathrm{A}_{260} / \mathrm{A}_{280}$ (Mekuria et al., 1999).

RAPD-PCR. Amplifications were carried out in a volume of 20 $\mu \mathrm{L}$ containing $1.5 \mathrm{~mm} \mathrm{MgCl}, 1 \times$ Taq DNA polymerase buffer $(67$ mm Tris-HCl pH 8.0, $16.6 \mathrm{~mm}\left(\mathrm{NH}_{4}\right)_{2} \mathrm{SO}_{4}, 0.45 \%$ Triton X-100, 0.2 $\mathrm{mg} \cdot \mathrm{mL}^{-1}$ gelatin), $200 \mu \mathrm{M}$ of dNTPs, $0.5 \mu \mathrm{M}$ of primer, and 1.1 unit of Taq DNA polymerase (Life Technologies). The PCR program consisted of an initial denaturation of $2 \mathrm{~min}$ at $95^{\circ} \mathrm{C}$, followed by

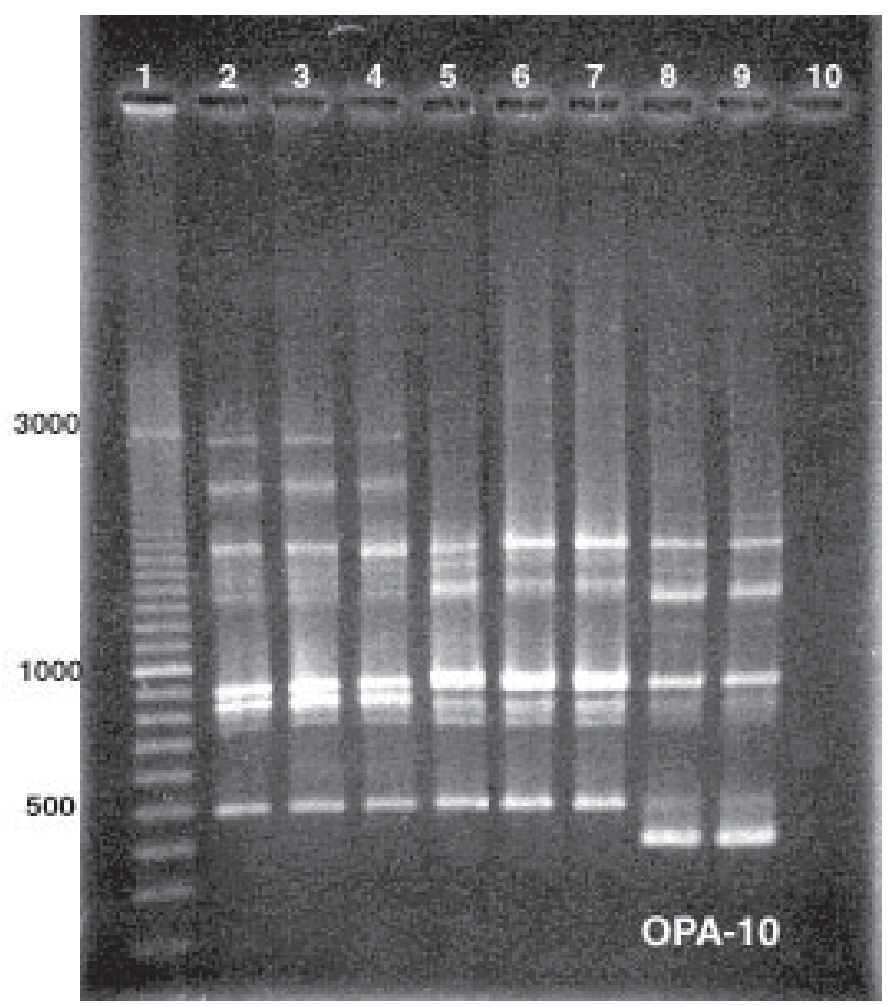

Fig. 1. DNA fingerprints of leaves from almond scions ('Ne Plus Ultra' and 'Nonpareil' selection 15-1) and the almond/peach hybrid rootstock (Prunus dulcis 'Titan' $\times$ P. persica 'Nemaguard'), produced from RAPD-PCR using random primer OPA-10.

Lane $1=$ molecular marker (100-bp ladder).

Lane $2=$ DNA of 'Ne Plus Ultra' from original orchard tree.

Lane 3 = DNA of 'Ne Plus Ultra' from in vitro cultures that were not cryopreserved.

Lane 4 = DNA of 'Ne Plus Ultra' from 3-d cryopreserved shoot tips.

Lane 5 = DNA of 'Nonpareil' 15-1 from original orchard tree.

Lane $6=$ DNA of 'Nonpareil' $15-1$ from in vitro cultures that were not cryopreserved.

Lane 7 = DNA of 'Nonpareil' 15-1 from 3-d cryopreserved shoot tips.

Lane $8=$ DNA of the hybrid rootstock from in vitro cultures that were not cryopreserved.

Lane $9=$ DNA of the hybrid rootstock from 3- cryopreserved shoot tips.

Lane $10=$ control (no DNA). 
39 cycles of $1 \mathrm{~min}$ at $95^{\circ} \mathrm{C}, 10 \mathrm{~s}$ at $50^{\circ} \mathrm{C}, 15 \mathrm{~s}$ at $45^{\circ} \mathrm{C}, 20 \mathrm{~s}$ at 40 ${ }^{\circ} \mathrm{C}, 1 \mathrm{~min}$ at $35^{\circ} \mathrm{C}, 30 \mathrm{~s}$ at $45^{\circ} \mathrm{C}, 1 \mathrm{~min} 45 \mathrm{~s}$ at $72{ }^{\circ} \mathrm{C}$, with a final extension step of $5 \mathrm{~min}$ at $72^{\circ} \mathrm{C}$ (Collins and Symons, 1993).

The 10-mer primers used were OPA-04 (5'-AATCGGGCTG), OPA-08 (5'-GTGACGTAGG), OPA-10 (5'-GTGACTGCAG), OPA-14 (5'-TCTGTGCTGG), OPA-18 (5'-AGGTGACCGT), OPB-04 (5'-GGACTGGAGT), and OPB-10 (5'-CTGCTGGGAC). Primers OPA-04, OPA-08, and OPA-10 were chosen from Woolley et al. (2000). Primers OPA-14, OPA-18, OPB-04, and OPB-10 were selected after a survey because they also produced clear polymorphic bands.

RESTRICTION DIGESTION WITH ENDONUCLEASES. The isoschizomer pairs Msp I/Hpa II and Bsp 143 I/Mbo I (GeneWorks, Australia) were used to digest genomic DNA (Table 1).

Digestions were carried out in a volume of $10 \mu \mathrm{L}$, containing $2 \mathrm{U}$ of enzyme, $1 \mu \mathrm{L}$ of universal buffer $(0.1 \mathrm{~m}$ Tris acetate, $\mathrm{pH}$ $7.5,0.5 \mathrm{~m}$ potassium acetate, $0.01 \mathrm{~m}$ spermidine, $0.01 \mathrm{M}$ dithioerythritol), and $500 \mathrm{ng}$ of genomic DNA, at $37^{\circ} \mathrm{C}$ for $3 \mathrm{~h}$.

Assessment of GENETIC STABILITY. Genomic DNA was subjected either to RAPD-PCR alone, or to a combination of restriction digestion with either Hpa II, Msp I, Bsp 143 I, or Mbo I, followed by RAPD-PCR. DNA fragments were separated on $1.5 \%$ agarose in TBE buffer ( $89 \mathrm{~mm}$ Tris $\mathrm{HCl}$, pH 8.3, $89 \mathrm{~mm}$ boric acid, $5 \mathrm{~mm}$ EDTA), at $80 \mathrm{~mA}$ constant current, and the sizes of the products estimated against a 100-bp ladder (GeneWorks, Australia). Gels were stained with ethidium bromide $\left(0.2 \mu \mathrm{g} \cdot \mathrm{mL}^{-1}\right)$, and photographed under UV light with Polaroid film. The gel image was also captured by the Tekcap computer program (Version 1.0, Tekram Corporation, 1998), and scanned to disk via Paintshop Pro software (Version 5.0, Jasc Software Inc. 1998). DNA fingerprints on the Polaroid films were compared by eye, and polymorphisms were confirmed with the scanned images. At least two separate, complete tests were carried out on each sample of DNA.

The methylation status of the genomic DNA was assessed by comparing the gel images from each isoschizomer pair of restriction enzymes. From Table 1, for the isoschizomer pair $\mathrm{Hpa}$ II/Msp I, Hpa II was classed as methylation sensitive and Msp I as methylation insensitive (Harding et al., 1996; Kaeppler et al., 1993), and for the isoschizomer pair Bsp 143 I/Mbo I, Bsp 143 I was classed as methylation sensitive and $M b o$ I as methylation insensitive (Franks et al., 1998; Weber et al., 1990).

Within each pair of isoschizomers, the following assumptions were made for a test between two samples of DNA:

1. If both enzymes produced the same fingerprint then the two

Table 2 Effect of in vitro culture and cryopreservation of 'Nonpareil' selection 15-1 on changes to methylation and structure of DNA. DNA samples were digested with one of four restriction endonucleases and then subjected to RAPD-PCR with six primers.

\begin{tabular}{|c|c|c|c|c|c|c|c|c|c|c|c|}
\hline \multirow[b]{2}{*}{ Primer } & \multirow[b]{2}{*}{ Enzyme } & \multirow[b]{2}{*}{$\begin{array}{l}\text { Orchard } \\
\text { trees }^{z}\end{array}$} & \multirow[b]{2}{*}{$\begin{array}{l}\text { In vitro } \\
\text { cultures }\end{array}$} & \multicolumn{2}{|c|}{$\begin{array}{c}\text { Cryopreserved } \\
\text { cultures }^{z}\end{array}$} & \multicolumn{2}{|c|}{$\begin{array}{l}\text { Regrown } \\
\text { plants }^{y}\end{array}$} & \multicolumn{2}{|c|}{$\begin{array}{c}\text { Control in vitro } \\
\text { cultures } \\
\text { without } \mathrm{LN}^{\mathrm{x}}\end{array}$} & \multicolumn{2}{|c|}{$\begin{array}{c}\text { Changes } \\
\text { compared to } \\
\text { orchard trees }\end{array}$} \\
\hline & & & & $\begin{array}{l}\mathrm{LN} \\
(3 \mathrm{~d})\end{array}$ & $\begin{array}{c}\mathrm{LN} \\
(24 \mathrm{mo})\end{array}$ & $\begin{array}{l}\text { In vitro } \\
\text { culture }\end{array}$ & $\begin{array}{l}\mathrm{LN} \\
(3 \mathrm{~d})\end{array}$ & $\begin{array}{l}\text { Non- } \\
\text { treated }\end{array}$ & $\begin{array}{l}\text { PVS2- } \\
\text { treated }\end{array}$ & $\begin{array}{c}\text { More } \\
(+)\end{array}$ & $\begin{array}{c}\text { Less } \\
(-)\end{array}$ \\
\hline \multirow[t]{3}{*}{$\overline{\mathrm{OPA}-04}$} & $* M s p$ I & $-{ }^{w}$ & - & - & - & - & - & - & - & & \\
\hline & *Hpa II & $2^{v}$ & 2 & 2 & - & - & - & 2 & 2 & 1270,500 & \\
\hline & $* M b o$ I & - & - & - & - & - & - & - & - & & \\
\hline \multirow{3}{*}{ OPA-08* } & **Hpa II & 1 & 1 & 1 & - & - & - & 1 & 1 & 650 & \\
\hline & $* * * M b o \mathrm{I}$ & - & 1 & 1 & 1 & 1 & 1 & 1 & 1 & 800 & \\
\hline & $* * B s p 143 \mathrm{I}$ & - & 2 & 2 & 2 & 2 & 2 & 2 & 2 & 880,800 & \\
\hline \multirow[t]{2}{*}{ OPA-10 } & $M s p \mathrm{I}$ & - & - & - & - & - & - & - & - & & \\
\hline & Hра II & - & - & - & - & - & - & - & - & & \\
\hline \multirow{2}{*}{ OPA-18 } & ${ }^{*} M b o \mathrm{I}$ & - & - & - & - & - & - & - & - & & \\
\hline & $* * B s p 143 \mathrm{I}$ & $2^{u}$ & 1 & 1 & 1 & 1 & 1 & 1 & 1 & $800^{\mathrm{u}}, 470$ & \\
\hline \multirow[t]{4}{*}{ OPB-04 } & $M s p \mathrm{I}$ & - & - & - & - & - & - & - & - & & \\
\hline & Hра II & - & - & - & - & - & - & - & - & & \\
\hline & $* M b o \mathrm{I}$ & - & - & - & - & - & - & - & - & & \\
\hline & $* * B s p 143 \mathrm{I}$ & $5^{u}$ & 4 & 4 & 4 & 4 & 4 & 4 & 4 & $1050,950,850^{u}$ & 1550,530 \\
\hline \multirow[t]{4}{*}{ OPB-10 } & $M s p \mathrm{I}$ & - & - & - & - & - & - & - & - & & \\
\hline & Hpa II & - & - & - & - & - & - & - & - & & \\
\hline & $* M b o \mathrm{I}$ & - & - & - & - & - & - & - & - & & \\
\hline & *Bsp 143 I & 2 & 2 & 2 & 2 & 2 & 2 & 2 & 2 & 1300,900 & \\
\hline
\end{tabular}

zThree samples from one tree for in vitro cultures and for cryopreservation, with two replications of RAPD for each primer.

yFor plants regrown from in vitro cultures and cryopreserved cultures, three samples from three plants were used, with two replications of RAPD for each primer.

xFor the control, three samples were used in each treatment, with two replications of RAPD for each primer.

w(-)Represents the original fingerprint pattern obtained from orchard trees produced by Msp I or Mbo I for each primer.

vNumber indicates the numbers of bands (present or absent) different from the original patterns produced by Msp I or Mbo I from orchard trees for each primer.

uBand detected in the orchard trees but missing in others. *Methylation detected between isoschizomer pair, **methylation detected with the restriction enzyme, $* * *$ structural change, $\mathrm{LN}=$ liquid nitrogen. 
DNA samples are identical,

2. If change for methylation sensitive and no change for methylation insensitive then the DNA samples show a change in methylation,

3 . If change for methylation insensitive and no change for methylation sensitive then the DNA samples show a change in methylation or structure,

4. If change for methylation sensitive and change for methylation insensitive then the DNA samples show a change in both structure and methylation,

5. If change within methylation insensitive then the DNA samples show a change in structure.

\section{Results}

RECOVERY FROM CRYOPRESERVATION. The mean survival after thawing was $80 \%$ for 'Ne Plus Ultra', 54\% for 'Nonpareil', and
$78 \%$ for the hybrid rootstock . There were no significant differences between the survivals at day 3 and at month 24, and all shoots appeared to be morphologically normal.

ANALYSIS OF GENETIC STABILITY USING RAPD-PCR. For 'Nonpareil' and 'Ne Plus Ultra', each of the seven 10-mer primers produced identical fingerprints for the leaf DNA extracted from the original orchard trees, and from plants regrown from in vitro cultures before cryopreservation, and after cryopreservation for 3 d. For the hybrid rootstock, each of the primers produced identical fingerprints for the leaf DNA extracted from in vitro cultures before cryopreservation, and after cryopreservation for $3 \mathrm{~d}$. The result for one of the primers, OPA-10, is shown in Fig. 1.

ANALYSIS OF GENETIC STABILITY OF 'NONPAREIL' BY RESTRICTION

Fig. 2. Effect of in vitro culture and cryopreservation of 'Nonpareil' selection 15-1 on changes to methylation and structure of DNA. DNA samples were digested with one of four restriction endonucleases and then subjected to RAPD-PCR with primer OPA- 18 .

Lane $1,8,15,17$, and $30=$ Molecular marker (100-bp ladder).
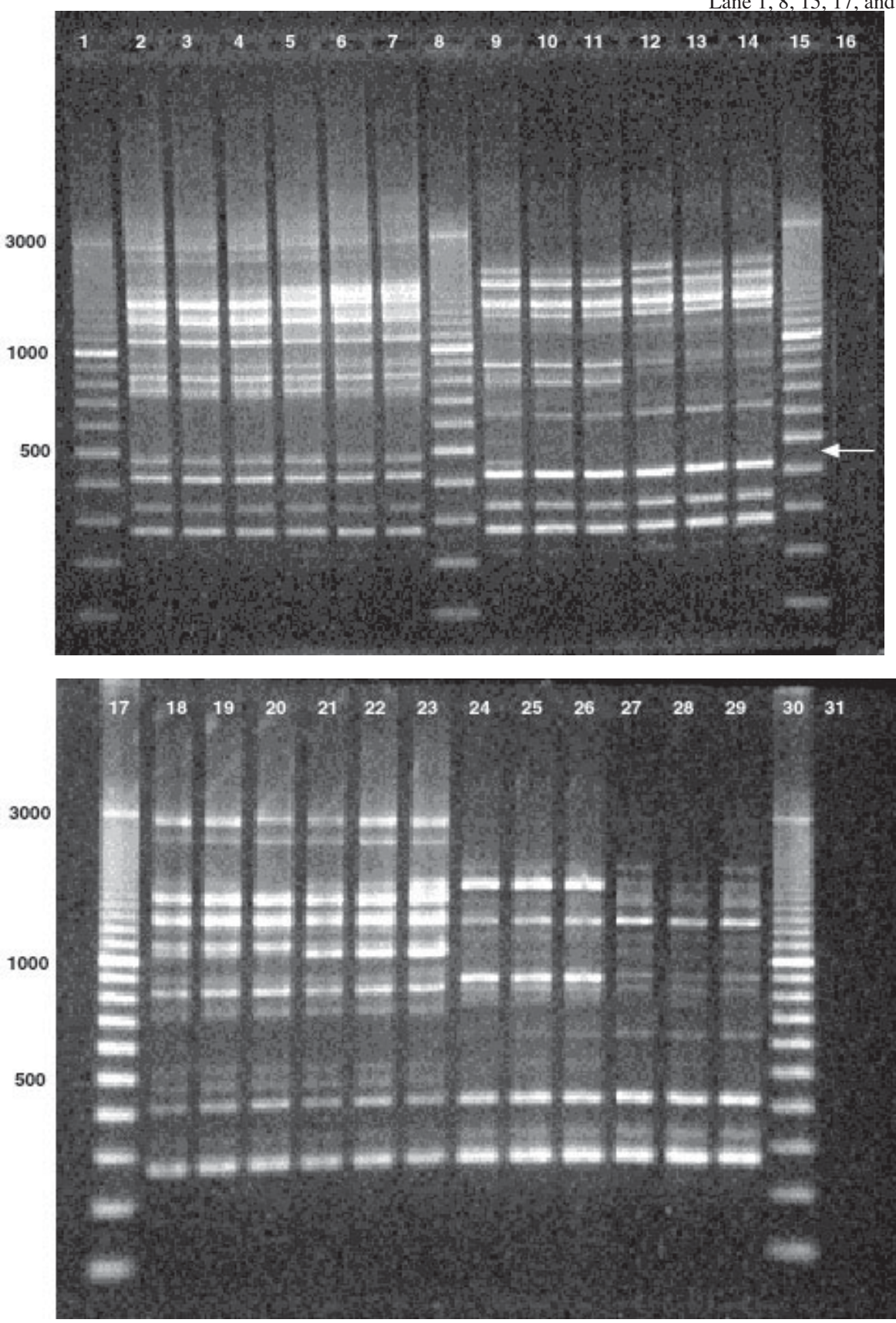

Lane 16 and $31=$ Control (no DNA).

Lane 2 $=$ DNA of leaves from original orchard tree digested with $\mathrm{Hpa}$ II.

Lane $3=$ DNA of leaves regrown from in vitro cultures that were not cryopreserved digested with $\mathrm{Hpa}$ II.

Lane 4 = DNA of leaves regrown from 3-d cryopreserved shoot tips digested with $\mathrm{Hpa}$ II.

Lane $5=$ DNA of leaves from original orchard tree digested with $M s p$ I.

Lane $6=$ DNA of leaves regrown from in vitro cultures that were not cryopreserved digested with $M s p$ I.

Lane 7 = DNA of leaves regrown from 3-d cryopreserved shoot tips digested with $M s p$ I.

Lane $9=$ DNA of leaves from original orchard tree digested with $B s p 143$ I (arrow indicates an extra band).

Lane $10=$ DNA of leaves regrown from in vitro cultures that were not cryopreserved digested with Bsp $143 \mathrm{I}$.

Lane $11=$ DNA of leaves regrown from 3-d cryopreserved shoot tips digested with Bsp 143 I.

Lane 12 = DNA of leaves from original orchard tree digested with $M b o$ I.

Lane $13=$ DNA of leaves regrown from in vitro cultures that were not cryopreserved digested with $M b o \mathrm{I}$.

Lane $14=$ DNA of leaves regrown from 3-d cryopreserved shoot tips digested with $M b o \mathrm{I}$.

Lane $18=$ DNA of leaves regrown from 24-month cryopreserved shoot tips digested with Hpa II.

Lane 19= DNA of leaves from plant grown regenerated from 3-d cryopreserved shoot tips digested with $\mathrm{Hpa}$ II.

Lane $20=$ DNA of leaves from plant grown regenerated from in vitro cultures that were not cryopreserved digested with $H p a$ II.

Lane 21 = DNA of leaves regenerated from 24-month cryopreserved shoot tips digested with Msp I.

Lane 22 = DNA of leaves from plant regenerated from 3-d cryopreserved shoot tips digested with Msp I.

Lane 23 = DNA of leaves from plant regenerated from in vitro cultures that were not cryopreserved digested with $M s p$ I.

Lane 24 = DNA of leaves regenerated from 24-month cryopreserved shoot tips digested with Bsp 143 I.

Lane 25 = DNA of leaves from plant regenerated from 3-d cryopreserved shoot tips digested with $B s p 143$ I.

Lane 26 = DNA of leaves from plant regrown from in vitro cultures that were not cryopreserved digested with Bsp 143 I.

Lane 27 = DNA of leaves regrown from 24-month cryopreserved shoot tips digested with $M b o$ I.

Lane 28 = DNA of leaves from plant regrown from 3-d cryopreserved shoot tips digested with $M b o$ I.

Lane 29 = DNA of leaves from plant regrown from in vitro cultures that were not cryopreserved digested with $M b o$ I 
DIGESTION FOLLOWED BY RAPD-PCR. The isoschizomer enzyme pairs resulted in different fingerprints for each of the six primers used (Table 2), and the result for one of the primers, OPA-18, is shown in Fig. 2.

Except for $M s p \mathrm{I} / \mathrm{Hpa}$ II with primers OPA-10, OPA-18, OPB04, and OPB-10, the other eight combinations of restriction enzymes and 10-mer primers resulted in differences in amplification between orchard trees and in vitro cultures. For primers OPA-04, OPA-08, OPA-18, and OPB-04, differences occurred between the DNA fingerprints of the DNA samples. In the case Hpa II followed by amplification with OPA-04, changes in methylation were detected in orchard trees, in vitro cultures, cryopreserved cultures after $3 \mathrm{~d}$, and the nontreated and PVS2-treated cultures, but these were absent after 24 months of cryopreservation, and in plants that were regrown from in vitro cultures. For $M b o \mathrm{I} / B s p$ 143 I with OPA-08, OPA-18, and OPB-04, the DNA fingerprints of the in vitro cultures and the original trees were different for Bsp 143 I alone, and for the isoschizomer pair. In addition, for OPA-08, differences were found for Mbo I alone.

For primers OPA-04 and OPA-08, digestion with Hpa II before PCR resulted in different fingerprints to those obtained after $M s p$ I digestion, for cultures cryopreserved for $3 \mathrm{~d}$ compared to those cryopreserved for 24 months. These changes did not appear to be associated directly with the use of the cryoprotectant, PVS2.

Analysis of genetic stability of 'Ne Plus Ultra' by ReSTRICTION DIGESTION FOLLOWED BY RAPD-PCR. The isoschizomer enzyme pairs resulted in different fingerprints for each of the six primers used (Table 3).

Except for Msp I/Hpa II with primers OPA-04, OPA-08, OPA18 , and OPB-04, the other eight combinations of restriction enzymes and 10-mer primers resulted in the detection of differences between orchard trees and in vitro cultures. For primers OPA-10, OPA-18, OPB-04, and OPB-10, differences occurred between the DNA fingerprints of the DNA samples. With these four primers, the DNA fingerprints of the in vitro cultures and the original trees were different for $B s p 143$ I alone, and for the isoschizomer pair Mbo I/Bsp 143 I. In addition, for OPA-10, differences were found for $M b o$ I alone. In the case of $M s p$ I followed by amplification with OPB-10, changes in methylation were detected after 24 months of cryopreservation, and in plants that were regrown from shoot tips that were cryopreserved for $3 \mathrm{~d}$, but were absent in orchard trees, in vitro cultures, cryopreserved cultures after $3 \mathrm{~d}$, and the nontreated and PVS2-treated cultures.

For primer OPB-10, digestion with Hpa II before PCR resulted

Table 3 Effect of in vitro culture and cryopreservation of 'Ne Plus Ultra' on changes to methylation and structure of DNA. DNA samples were digested with one of four restriction endonucleases and then subjected to RAPD-PCR with six primers.

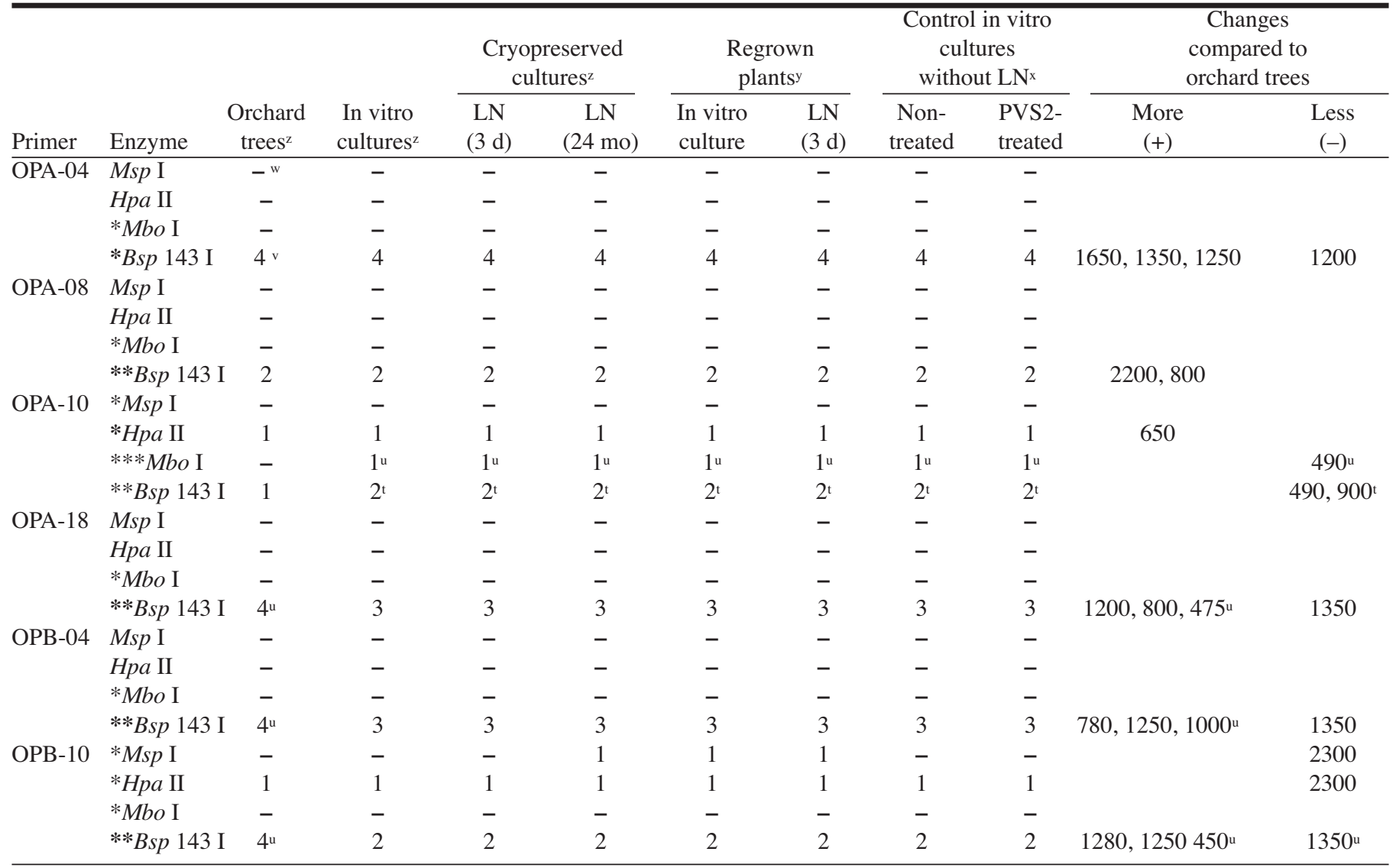

zThree samples from one tree for in vitro cultures and for cryopreservation, with two replications of RAPD for each primer.

yFor plants regrown from in vitro cultures and cryopreserved cultures, three samples from three plants were used, with two replications of RAPD for each primer.

${ }^{x}$ For control, three samples were used in each treatment, with two replications of RAPD for each primer.

w(-)Represents the original fingerprint pattern obtained from orchard trees produced by Msp I or Mbo I for each primer.

vNumber indicates the numbers of bands (present or absent) different from the original patterns produced by Msp I or Mbo I from orchard trees for each primer

u/tBands detected in the orchard trees, from Mbo I or Bsp 143 I respectively, but missing in others. * Methylation detected between isoschizomer pair, **methylation detected with the restriction enzyme, ***structural change, $\mathrm{LN}=$ liquid nitrogen. 
Table 4 Effect of in vitro culture and cryopreservation of the almond/peach hybrid rootstock ( $P$. dulcis 'Titan' $\times P$. persica 'Nemaguard') on changes to methylation and structure of DNA. DNA samples were digested with one of four restriction endonucleases and then subjected to RAPD-PCR with six primers.

\begin{tabular}{|c|c|c|c|c|c|c|c|c|c|c|}
\hline \multirow[b]{2}{*}{ Primer } & \multirow[b]{2}{*}{ Enzyme } & \multirow[b]{2}{*}{$\begin{array}{l}\text { In vitro } \\
\text { cultures }^{\mathrm{z}}\end{array}$} & \multicolumn{2}{|c|}{$\begin{array}{c}\text { Cryopreserved } \\
\text { cultures }^{z}\end{array}$} & \multicolumn{2}{|c|}{$\begin{array}{l}\text { Regrown } \\
\text { plantsy }\end{array}$} & \multicolumn{2}{|c|}{$\begin{array}{c}\text { Control in vitro } \\
\text { cultures } \\
\text { without } \mathrm{LN}^{\mathrm{x}}\end{array}$} & \multicolumn{2}{|c|}{$\begin{array}{c}\text { Changes } \\
\text { compared to } \\
\text { in vitro cultures }\end{array}$} \\
\hline & & & $\begin{array}{l}\mathrm{LN} \\
(3 \mathrm{~d})\end{array}$ & $\begin{array}{c}\mathrm{LN} \\
(24 \mathrm{mo})\end{array}$ & $\begin{array}{l}\text { In vitro } \\
\text { culture }\end{array}$ & $\begin{array}{l}\mathrm{LN} \\
(3 \mathrm{~d})\end{array}$ & $\begin{array}{l}\text { Non- } \\
\text { treated }\end{array}$ & $\begin{array}{l}\text { PVS2- } \\
\text { treated }\end{array}$ & $\begin{array}{l}\text { More } \\
(+)\end{array}$ & $\begin{array}{c}\text { Less } \\
(-)\end{array}$ \\
\hline \multirow[t]{3}{*}{ OPA-04 } & $M s p \mathrm{I}$ & $-w$ & - & - & - & - & - & - & & \\
\hline & Hра II & - & - & - & - & - & - & - & & \\
\hline & $* M b o \mathrm{I}$ & - & - & - & - & - & - & - & & \\
\hline \multirow[t]{4}{*}{ OPA-08 } & $M s p \mathrm{I}$ & - & - & - & - & - & - & - & & \\
\hline & Hpa II & - & - & - & - & - & - & - & & \\
\hline & $* M b o \mathrm{I}$ & - & - & - & - & - & - & - & & \\
\hline & *Bsp 143 I & 4 & 4 & 4 & 4 & 4 & 4 & 4 & $2050,500,480$ & 600 \\
\hline \multirow[t]{2}{*}{ OPA-10 } & $* M s p \mathrm{I}$ & - & - & - & - & - & - & - & & \\
\hline & *Hpa II & 1 & 1 & 1 & 1 & 1 & 1 & 1 & & 890 \\
\hline \multirow{2}{*}{ OPA-18 } & $* M b o \mathrm{I}$ & - & - & - & - & - & - & - & & \\
\hline & *Bsp 143 I & 1 & 1 & 1 & 1 & 1 & 1 & 1 & 2100 & \\
\hline \multirow[t]{4}{*}{ OPB-04 } & $* M s p \mathrm{I}$ & - & - & - & - & - & - & - & & \\
\hline & *Hpa II & 2 & 2 & 2 & 2 & 2 & 2 & 2 & & 2800,1300 \\
\hline & $* M b o$ I & - & - & - & - & - & - & - & & \\
\hline & *Bsp 143 I & 2 & 2 & 2 & 2 & 2 & 2 & 2 & 1050,750 & \\
\hline \multirow[t]{4}{*}{ OPB-10 } & $M s p \mathrm{I}$ & - & - & - & - & - & - & - & & \\
\hline & Нра II & - & - & - & - & - & - & - & & \\
\hline & $* M b o$ I & - & - & - & - & - & - & - & 1400 & \\
\hline & ${ }^{*} B s p 143$ I & 1 & 1 & 1 & 1 & 1 & 1 & 1 & 1400 & \\
\hline
\end{tabular}

zThree samples from one tree for in vitro cultures and for cryopreservation, with two replications of RAPD for each primer.

yFor plants regrown from in vitro cultures and cryopreserved cultures, three samples from three plants were used, with two replications of RAPD for each primer.

xFor the control, three samples were used in each treatment, with two replications of RAPD for each primer.

w(-)Represents the original fingerprint pattern obtained from in vitro cultures produced by Msp I or Mbo I for each primer.

vnumber indicates the numbers of bands (present or absent) different from the original patterns produced by $M s p$ I or Mbo I from in vitro cultures for each primer. *Methylation detected between isoschizomer pair, $\mathrm{LN}=$ liquid nitrogen.

in different fingerprints to those obtained after Msp I digestion, for cultures cryopreserved for $3 \mathrm{~d}$ compared to those cryopreserved for 24 months. These changes did not appear to be associated directly with the use of the cryoprotectant, PVS2.

ANALYSIS OF GENETIC STABILITY OF THE HYBRID ROOTSTOCK BY RESTRICTION DIGESTION FOLLOWED BY RAPD-PCR. The pattern of polymorphic bands produced by the hybrid rootstock is shown in Table 4. Except for Msp I/Hpa II with primers OPA-04, OPA-08, and OPB-10, the other nine combinations of restriction enzymes and 10-mer primers resulted in the detection of methylated DNA in the cultures. There were no detectable differences in DNA fingerprints between in vitro cultures before cryopreservation, plants regenerated from in vitro cultures before cryopreservation, plants regrown after cryopreservation for $3 \mathrm{~d}$, and plants regrown after cryopreservation for 24 months.

EFFECT OF VITRIFICATION SOLUTION (PVS2) ON GENETIC STABILITY. DNA prepared from leaves regrown from in vitro cultures of 'Nonpareil', 'Ne Plus Ultra', and the hybrid rootstock, treated with and without the vitrification solution, PVS2, showed no detectable differences when subjected to restriction digestion followed by RAPD-PCR with six 10-mer primers (Tables 2, 3, and 4).

\section{Discussion}

The genetic stability of shoots regrown from both in vitro cultures and from shoot tips after cryopreservation was assessed initially by using RAPD-PCR with seven different 10 -mer primers. For 'Nonpareil' and 'Ne Plus Ultra', there were no detectable differences between the fingerprints produced by DNA from the leaves of the original trees, leaves of plants regrown from in vitro cultures of leaf explants, and leaves of plants regrown from shoot tips that had been cryopreserved for $3 \mathrm{~d}$. For the almond-peach hybrid rootstock, which was obtained in culture, there were no differences between DNA from leaves of plants regrown from in vitro cultures, and leaves of plants regrown from shoot tips that had been cryopreserved for $3 \mathrm{~d}$. A similar result was obtained by Helliot et al. (1999) with cryopreserved meristems of Prunus Ferlenian rootstock, and by Goto et al. (1998) with micropropagated shoots of Pinus thunbergii. However, De Vernoetal. (1999) detected DNA polymorphisms and somaclonal variation between plants of white spruce regenerated from cultures before and after cryopreservation.

In the present study, the sensitivity of detecting changes to both structure and methylation of DNA was improved by subjecting the DNA preparations to digestion with restriction endonucleases be- 
fore RAPD-PCR. Four enzymes, consisting of two isoschizomeric pairs, HpaII/MspI and Bsp $143 \mathrm{I} / \mathrm{MboI}$, were used singly to digest the DNA. Hpa II and Bsp 143 I, which are relatively methylation sensitive, were compared to Msp I and Mbo I, respectively, which are relatively methylation insensitive.

For both 'Nonpareil' and 'Ne Plus Ultra', the DNA fingerprints of the original trees produced by the isoschizomer pairs indicated that some degree of methylation was present. Also for both cultivars, several of the restriction enzyme-primer combinations produced different fingerprints between the original trees and the in vitro cultures, indicating a possible change in methylation. The results for Hpa II/OPA-04 in the case of 'Nonpareil', and Msp I/OPB-10 in the case of 'Ne Plus Ultra' suggest that some relatively short-term changes in methylation have been detected. Differences between the DNA of embryo callus cultures and that of the original trees was found by Hashmi et al. (1997). Kaeppler et al. (1993) found a high frequency of DNA methylation among regenerant-derived cultures, even from the same embryo source. The changes were heritable and stable upon selfing (Kaeppler et al., 1993). Harding et al. (1996) also found changes in methylation of genomic DNA in in vitro cultures, and in plantlets regenerated from the cultures.

Changes in DNA fingerprints between the leaves on the trees and the cultures derived from leaf explants were found for $M b o$ I/Bsp 143 I with OPA-10 in the case of 'Nonpareil', and with OPA08 in the case of 'Ne Plus Ultra'. This finding suggests the possibility that changes in the structure of DNA had occurred during the process of in vitro culture. These changes persisted through the cryopreservation process.

Amethylation change was detected between the DNA of shoots that had been regrown from shoot tips that were cryopreserved for $3 \mathrm{~d}$ compared to those from shoot tips that were cryopreserved for 24 months. This appeared with the combination of Msp I/Hpa II using OPA08 in the case of 'Nonpareil', and OPB10 in the case of 'Ne Plus Ultra'. However, before cryopreservation, these shoot tips had been taken from shoots that had been in in vitro culture for different lengths of time, and the change in methylation is therefore more likely to be due to different sub-culturing history rather than to the cryopreservation process. None of the changes detected could be ascribed directly to the use of the cryoprotectant, PVS2.

For the almond-peach hybrid rootstock, in vitro shoots were obtained from ForBio Research Pty. Ltd., and the source of the original explants is unknown. It is likely that the material that was obtained had already been through many subcultures, and this is the most likely explanation for the detection of changes in methylation in the cultures. Compared to 'Nonpareil' and ' $\mathrm{Ne}$ Plus Ultra', none of the combinations of restriction enzymes with 10 -mer primers resulted in any detectable differences due to the cryopreservation process.

Various factors are reported to affect recovery from cryopreservation, including plant conditions, differences in individual cryotubes, the particular thawing procedure for an individual cryotube, and other handling anomalies (Reed et al., 1998). No significant decline in recovery for cryopreserved dormant apple buds after 4 years was reported by Forsline et al. (1998), or for cryopreserved dormant mulberry buds for up to 5 years by Niino et al. (1994). In the present study, there were no significant differences in the recovery of almond shoot tips thawed after $3 \mathrm{~d}$ of cryopreservation, compared to those cryopreserved for 24 months.

Based on the results of regrowth of almond shoot tips after storage under liquid nitrogen, cryopreservation appears to offer a useful method for the long-term storage of almond germplasm. The finding that methylation of genomic DNA is altered during both in vitro culture and cryopreservation agrees with other reports. To avoid the problem of somaclonal variation associated with in vitro culture, it is suggested that plant material collected from original orchard trees should not be micropropagated on media for a long time, or pass through many subcultures.

Changes to the structure of DNA are a more important impediment to the use of cryopreservation to store almond germplasm, and its significance will be monitored in plants that are regrown from cryopreserved shoot tips, especially the agronomic performance of the plants when they become reproductively mature.

\section{Literature Cited}

Almehdi, A.A. and D.E. Parfitt. 1986. In vitro propagation of peach: I. Propagation of 'Lovell' and 'Nemagard' peach rootstocks. Fruit Var. J. 46:12-17.

Benson, E. and J. Hamill. 1991. Cryopreservation of post freeze molecular and biosynthetic stability in transformed roots of Betula vulgaris and Nicotiana rustica. Plant Cell Tiss. Organ Cult. 24:163-172.

Channuntapipat, C., G. Collins, T. Bertozzi, and M. Sedgley. 2000. Cryopreservation of in vitro almond shoots by vitrification. J. Hort. Sci. Biotechnol. 75:228-232.

Collins, G.G. and R.H. Symons. 1993. Extraction of nuclear DNA from grapevine leaves by a modified procedure. Plant Mol. Biol. Rpt. 10: 233-235.

De Verno, L.L., Y.S. Park, J.M. Bonga, and J.D. Barrett. 1999. Somaclonal variation in cryopreserved embryogenic clones of white spruce [Picea glauca (Moench) Voss.]. Plant Cell Rpt. 18:948-953.

Elleuch, H., C. Gazeau, H. David, and A. David. 1998. Cryopreservation does not affect the expression of a foreign sam gene in transgenic Papaver somniferum cells. Plant Cell Rpt. 18:94-98.

Forsline, P.L., L.E. Towill, J.W. Waddell, C. Stushnoff, W.F. Lamboy, and J.R. McFerson. 1998. Recovery and longevity of cryopreserved dormant apple buds. J. Amer. Soc. Hort. Sci. 123:365-370.

Franks, T., D.G. He, and M. Thomas. 1998. Regeneration of transgenic Vitis vinifera L. Sultana plants: Genotypic and phenotypic analysis. Mol. Breed. 4:321-333.

Goto, S., R.C. Thakur, and K. Ishii. 1998. Determination of genetic stability in long-term micropropagated shoots of Pinus thunbergii Parl. using RAPD markers. Plant Cell Rpt. 18:193-197.

Harding, K., E.E. Benson, and K.A. Roubelakis-Angelakis. 1996. Methylated DNA changes associated with the initiation and maintenance of Vitis vinifera in vitro shoot and callus cultures: A possible mechanism for age-related changes. Vitis 35:79-85.

Hashmi, G., R. Huettel, R. Meyer, L. Krusberg, and F. Hammerschlag. 1997. RAPD analysis of somaclonal varients derived from embry callus cultures of peach. Plant Cell Rpt. 16:624-627.

Helliot, B., D. Madur, M. Brison, E. Dirlewanger, and M.T. de Boucaud. 1999. Genetic stability analysis of cryopreserved Prunus Ferlenain rootstock by RAPD and AFLP, p. 249-250. In: A. Altman, M. Ziv, and S. Izhar (eds.). Plant biotechnology and in vitro biology in the $21^{\text {st }}$ century. Kluwer Academic Publ., Netherlands.

Kaeppler, S.M. and R.L. Phillips. 1993. Tissue culture-induced DNAmethylation variation in maize. Proc. Natl. Acad. Sci. USA 90:8773-8776.

Kovař́ik, A., R. Matyasek, A. Leitch, B. Gazdova, J. Fulnecek, and M. Bezdek. 1997. Variability in CpNpG methylation in higher plant genomes. Gene 204:25-33.

McClelland, M., M. Nelson, and E. Raschke. 1994. Effect of site-specific modification on restriction endonucleases and DNA modification methyltransferases. Nucleic Acids Res. 17:3640-3659.

Mekuria, G.T., G.G. Collins, and M. Sedgley. 1999. Genetic variability between different accessions of some common commercial olive cultivars. J. Hort. Sci. Biotechnol. 74:309-314.

Murashige, T. and F. Skoog. 1962. A revised medium for rapid growth and bioassays with tobacco cultures. Physiol. Plant. 15:473-497.

Niino, T., K. Shirata, and A. Sakai. 1994. Five-year storage of winter 
mulberry buds ( 376 cultivars) at $-135{ }^{\circ} \mathrm{C}$. Cryobiol. 31:605.

Niino, T., K. Tashiro, M. Suzuki, S. Ohuchi, J. Magoshi, and T. Akihama. 1997. Cryopreservation of in vitro-grown shoot tips of cherry and sweet cherry by one-step vitrification. Sci. Hort. 70:155-163.

Rao, V.R. and K.W. Riley. 1994. Review. The use of biotechnology for conservation and utilisation of plant genetic resources. Plant Genet. Resour. Nwsl. 97:3-18.

Reed, B.M., J. Denoma, J. Luo, Y. Chang, and L. Towill. 1998. Cryopreservation and long-term storage of pear germplasm. In Vitro Cell. Dev.-Plant 34:256-260.

Sakai, A., S. Kobayashi, and I. Oiyama. 1991. Survival by vitrification of nucellar cells of navel orange (Citrus sinensis var. brasiliensis Tanaka) cooled to $-196^{\circ} \mathrm{C}$. J. Plant Physiol. 137:465-470.

Stushnoff, C. and C. Fear. 1985. The potential use of in vitro storage for temperate fruit germplasm. A status report, IBPGR, Rome, p. 1-21. Takagi, H., N.T. Thinh, O.M. Islam, T. Senboku, and A. Sakai. 1997. Cryopreservation of in vitro-grown shoot tips of taro [Colocasia esculenta (L.) Schott] by vitrification. I. Investigation of basic conditions of the vitrification procedure. Plant Cell Rpt. 16:594-599.

Uemura, M. and A. Sakai. 1980. Survival of carnation (Dianthus caryophyllus L.) shoot apices frozen to the temperature of liquid nitrogen. Plant Cell Physiol. 21:85-94.

Weber, H., C. Ziechmann, and A. Graessmann. 1990. In vitro DNA methylation inhibits gene expression in transgenic tobacco. EMBO J. 13:4409-4415.

Woolley, F.M., G.G. Collins, and M. Sedgley. 2000. Application of DNA fingerprinting for the classification of selected almond [Prunus dulcis (Miller) D.A. Webb] cultivars. Austral. J. Expt. Agr. 40:995-1001. 